\title{
Reflections on a Trial Implementation of an E-Learning Solution in a Libyan University
}

\author{
Amal Rhema and Iwona Miliszewska \\ Victoria University, Melbourne, Victoria, Australia
}

\section{Amal.Rhema@live.vu.edu.au; Iwona.Miliszewska@vu.edu.au}

\begin{abstract}
E-learning is fast becoming an essential method of delivering education. Recently, many traditional education systems have shifted towards new methods of teaching and learning thanks to the proliferation of information and communication technologies (ICTs); this shift includes elearning initiatives undertaken in developing countries. This paper describes a pilot initiative introduced at the Department of Data Analysis of the Faculty of Accounting of the Aljabal Algharbi University in Gharian, Libya. The initiative was conceived in the context of a project that aimed at solving the Department's educational problems and improving the flexibility of its educational offering. This paper outlines the status of e-learning in the Department prior to the pilot project and presents an analysis of the strengths-weaknesses-opportunities-threats (SWOT) of the Department with respect to using web-based instruction. It discusses the details of project implementation and its capacity to support a new pedagogical framework ('before', 'during', and 'after' activities) for teaching and learning in the Department. Finally, the paper presents the reflections of students, instructors, and technical staff on the trial implementation of the e-learning solution and concludes with a set of proposed recommendations for the future.
\end{abstract}

Keywords: e-learning, developing country, web-based system, higher education, SWOT analysis, flexible learning.

\section{Introduction}

Over the past decade, the new technology tools have dramatically changed and transformed people's perspectives and practices with respect to communication methods and business practices, as well as their learning processes (UNESCO, 2002). This shift has influenced society, lifestyles and, especially, educational systems giving high priority to using technology as a tool to support the learning processes and to provide learners with the latest professional technological skills. This is particularly significant for developing countries, as they seek to improve their education systems but lack: (1) infrastructure and resources (Andersson \& Grönlund, 2009; Dhanarajan, 2001; Gulati, 2008; Heeks, 2002; Rajesh, 2003); (2) well trained and qualified teachers needed to

Material published as part of this publication, either on-line or in print, is copyrighted by the Informing Science Institute. Permission to make digital or paper copy of part or all of these works for personal or classroom use is granted without fee provided that the copies are not made or distributed for profit or commercial advantage AND that copies 1) bear this notice in full and 2) give the full citation on the first page. It is permissible to abstract these works so long as credit is given. To copy in all other cases or to republish or to post on a server or to redistribute to lists requires specific permission and payment of a fee. Contact HPublisher@InformingScience.orgH to request redistribution permission. carry out the development and manage the change (Gulati, 2008); (3) active, participative students, familiar with interactive learning (Andersson \& Grönlund, 2009; Eastmond, 2000; Evans, 2005; Sehrt, 2003); and (4), the ability to implement advanced educational practices on their own (Andersson \& Grönlund, 2009).

Like in most developing countries, the use of ICTs and the implementation of 
e-learning in Libya are still at an early stage (Hamdy, 2007; Rhema \& Miliszewska, 2010), and the Libyan education system is still a traditional system, based on face-to-face interactions and campus-based learning activities (Rhema, \& Miliszewska, 2010). This traditional classroom setting is not sufficient to assure effective and efficient communication between instructors and students outside classes and away from campus. Thus, other means of communication and teaching and learning have to be sought and introduced. E-learning appears to be a promising alternative. It can help address the educational gaps, and open up accessible educational opportunities.

E-learning seems to have provided responses to several educational problems in Libya, as illustrated by Rhema (2005) and Rhema and Miliszewska (2010). It afforded alternative ways of communicating with teachers and fellow students, provided a greater variety of learning resources and modalities, extended the flexibility and quality of group-work, and improved the opportunities for providing students with feedback on assessment tasks. Accordingly, the Libyan government plans to develop the existing ICT infrastructure and reform the entire educational process including the development of curricula, instruction, and communication, as well as teacher training and technical support (The General People's Committee of Education, 2008 cited in Rhema, \& Miliszewska, 2010).

This paper describes a pilot e-learning initiative introduced at the Department of Data Analysis in the Faculty of Accounting at the Aljabal Algharbi University in Gharian, Libya. The paper presents background information about the case study institution and outlines the SWOT (Strengths, Weaknesses, Opportunities and Threats) analysis of the case study towards the use of technology for educational purposes. It also describes a trial implementation of web-based instruction to support a new pedagogical framework for teaching and learning, and presents the reflections of the students, instructors, and technical staff on the trial implementation.

\section{Case Study Institution}

Currently in Libya there are 18 government universities located in the capital city, main cities and other regional areas. Al-Jabal Al-Gharbi University is one of the biggest regional universities; it is located almost 100KM southwest of the capital, Tripoli. The university includes several faculties (located in different cities in the state of Al-Jabal Al-Gharbi) and each faculty is divided into several departments. The University offers qualifications in the disciplines of accounting, economics, management, information systems, law, languages, arts and media, social science, political science, Arabic and Islamic studies, medical science, and electrical engineering. It has a student population of 20,000 and nearly 1,000 instructors. The Faculty of Accounting (the first nucleus of the University) includes four departments Accounting, Data Analysis, Economics, and Management. The Department of Data Analysis (DDA) provides educational services and carries out research in the field of e-commerce applications; it has a population of 60 students and 17 instructors.

Since the Department is at an early stage of using technology for teaching and learning, it relies on traditional ways of providing education as well as assistance to students. The instructors use face-to-face approach to teaching and communicate in person with each other and with their students. However, the Department is the biggest user of computers in the Faculty of Accounting, as computers are widely used for teaching and learning to perform financial analyses, financial modelling, and related computations. The Department has two computer laboratories, equipped with nearly 60 computers. In addition, computers are also used to facilitate the processing of student records and general office work in the Department; this includes the use of databases and a student record management system. 


\section{SWOT Analysis of the Case Study}

SWOT analysis is the most common technique to evaluate the opportunities, threats, strengths and weaknesses of an organization (Ghazinoory, Zadeh \& Memariani, 2007; Leigh, 2010; Yuksel $\&$ Dag deviren, 2007). Thus, it is a useful method for identifying how an e-education strategy will fit and match with resources and capabilities of an educational institution (Chan \& Welebir, 2003; Mohammad, 2008). SWOT is used to develop a plan that takes into consideration many different internal and external factors, and maximizes the potential of the strengths and opportunities while minimizing the impact of the weaknesses and threats (Ghazinoory, Zadeh \& Memariani, 2007); elements of the SWOT framework are illustrated in Figure 1.

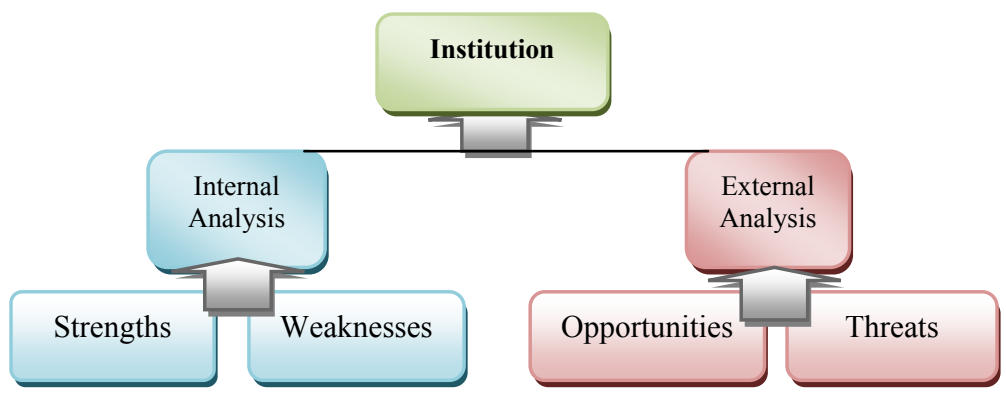

Figure 1: SWOT analysis framework

According to Chan \& Welebir (2003) and Mohammad (2008), SWOT is helpful for determining an institution's current situation and for planning and designing what direction to take next. Currently, a large number of initiatives are in progress in developing countries to adapt existing elearning technologies in higher education institutions. During this process, various kinds of customisations and modifications have to be considered to account for country-specific differences such as learner backgrounds, culture, and language (Richter \& Pawlowski, 2007); these differences can be a barrier to achieving the objectives of e-learning (Hodgkinson-Williams, Siebörger $\&$ Terzoli, 2007). The implementation of e-learning in an institutional setting requires inclusive strategic planning. Changing the educational offering through technology requires utilizing effective implementation plans and strategies. For instance, e-learning course planning is needed to develop course content that includes pedagogical underpinnings and is suited for e-learning delivery (Boulton, 2008; Khan, 2005). Careful attention to various sub-strategies and adequate preparation to facilitate the e-learning adoption are also required to ensure smooth and successful integration of e-learning across an organization (Lin, 2008).

Artemi \& Kuma (2009) present a critical review of research pertinent to a SWOT analysis of an e-learning model for Libyan educational institutions. The review recommends that the institutions should start working hard on minimizing the weaknesses such as poor English skills of students as well as instructors, lacking ICT infrastructure, and lack of e-learning know-how. Also, to relieve the threats, they recommend the use of a blended model (a combination of traditional and e- 
learning methods). Thus, SWOT analysis is an essential step to analyse various factors before implementing an e-learning solution at any institution.

The SWOT analysis carried out in the Department of Data Analysis aimed to help the decision makers at the Department on its areas of strength and greatest opportunities with respect to elearning. The analysis was based on the experiences with the institution in general and the DDA in particular of one of the authors of this article (as she was a student, assistant technical staff member, and instructor at DDA), as well as the perspectives of the instructors, students, administrators, and technical staff towards using web-based instruction. The information was obtained through individual interviews with eight students, four academics, two administrators, and two technical staff from the DDA. The outcomes of the analysis are illustrated in Table 1.

Table 1: SWOT analysis of e-learning in the Data Analysis Department

\begin{tabular}{|c|c|c|c|c|}
\hline & \multicolumn{2}{|c|}{ Internal Analysis } & \multicolumn{2}{|c|}{ External Analysis } \\
\hline & Strengths & Weaknesses & Opportunities & Threats \\
\hline 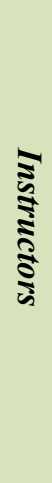 & $\begin{array}{l}\text { - motivation and } \\
\text { dedication } \\
\text { - expertise in using } \\
\text { computers }\end{array}$ & $\begin{array}{l}\text { lack of experience in } \\
\text { teaching with new tech- } \\
\text { nologies } \\
\text { - lack of willingness of } \\
\text { learn and adopt new } \\
\text { teaching methods } \\
\text { (flexible learning) } \\
\text { - insufficient space and } \\
\text { time for learning new } \\
\text { technologies } \\
\text { - poor English skills }\end{array}$ & $\begin{array}{l}\text { faculty development } \\
\text { opportunities (sabbatical } \\
\text { or scientific leaves, pro- } \\
\text { fessional meeting atten- } \\
\text { dance professional devel- } \\
\text { opment seminars and } \\
\text { workshops) } \\
\text { various funding opportu- } \\
\text { nities for improving the } \\
\text { educational methodology }\end{array}$ & $\begin{array}{l}\text { the possibility of los- } \\
\text { ing faculty members } \\
\text { with expertise in e- } \\
\text { learning } \\
\text { - lack of strong industry } \\
\text { cooperation for the } \\
\text { development of new } \\
\text { technologies } \\
\text { declining enrolment } \\
\text { (interest) in fields that } \\
\text { use e-learning }\end{array}$ \\
\hline$\frac{\sqrt{\pi}}{\frac{\pi}{3}}$ & $\begin{array}{l}\text { - student ability to } \\
\text { face challenges } \\
\text { - student willing- } \\
\text { ness to accept } \\
\text { changes }\end{array}$ & $\begin{array}{l}\text { - the lack of motivation } \\
\text { - lack of tutors (graduate } \\
\text { students) with experi- } \\
\text { ence in e-learning } \\
\text { - inadequate language } \\
\text { skills } \\
\text { - inadequate in critical or } \\
\text { analytical thinking }\end{array}$ & $\begin{array}{l}\text { - student development } \\
\text { opportunities in the De- } \\
\text { partment (computer } \\
\text { courses, English courses) } \\
\text { - excellent faculty as role } \\
\text { models and mentors } \\
\text { - possibility to influence } \\
\text { the high school curricu- } \\
\text { lum } \\
\text { - increased student enrol- } \\
\text { ment in the Department }\end{array}$ & $\begin{array}{l}\text { - increasing proportion } \\
\text { of new faculty with } \\
\text { relatively less experi- } \\
\text { ence and/or interest in } \\
\text { teaching (focused on } \\
\text { research) } \\
\text { - emerging local and } \\
\text { regional competition }\end{array}$ \\
\hline
\end{tabular}




\begin{tabular}{|c|c|c|c|c|}
\hline 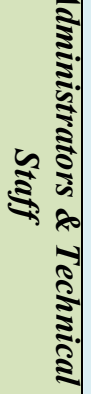 & $\begin{array}{l}\text { - well-equipped } \\
\text { laboratories } \\
\text { - availability of } \\
\text { computer based } \\
\text { infrastructure }\end{array}$ & $\begin{array}{l}\text { lack of competent tech- } \\
\text { nical support staff and } \\
\text { graduate students for } \\
\text { projects and lab devel- } \\
\text { opment } \\
\text { - inadequate space for } \\
\text { expansion of labs } \\
\text { - centralised decision } \\
\text { making process }\end{array}$ & $\begin{array}{l}\text { - currently sufficient fund- } \\
\text { ing } \\
\text { - competent faculty for } \\
\text { supervising lab develop- } \\
\text { ment } \\
\text { - new campus project }\end{array}$ & $\begin{array}{l}\text { - the need to keep up } \\
\text { with the fast pace of } \\
\text { developments (espe- } \\
\text { cially in IT) } \\
\text { - future budgetary limi- } \\
\text { tations } \\
\text { - changes in policy and } \\
\text { regulation in higher } \\
\text { education in Libya }\end{array}$ \\
\hline
\end{tabular}

The SWOT analysis of the DDA indicated that the introduction of web-based instruction (elearning) was likely to be successful, considering the Department's strengths: wide use of computers for teaching and learning, well-equipped computer laboratories and, good computing skills among instructors and students. However, the DDA needed to take action to minimize its weaknesses including poor English skills among students and instructors, and lack of experience in teaching and learning with new technologies. The success of e-learning initiatives was also likely to be improved by exploration of the available opportunities and using them to counter the potential threats. An introduction of a reward scheme for instructors willing to develop e-learning expertise might be one opportunity worth pursuing; such a scheme might counter the threat of losing existing instructors and encouraging others to be involved in e-learning initiatives. The outcomes of the SWOT analysis of the DDA support the findings reported by Artemi and Kuma (2009) who reviewed research pertinent to SWOT analysis of e-learning for Libyan educational institutions.

\section{Trial Implementation of an E-learning Solution}

"Developments are often led by the enthusiasm of individuals, with little external support or reward" (Vrana, Fragidis, Zafiropoulos \& Paschaloudis, n.d.). Recently, one of the instructors at the DDA has decided to take a more active role to improve student learning outcomes and course flexibility, by tackling some perennial educational problems in the Department. Those problems included difficulty to conduct meaningful revisions at the beginning of each class, hindered by limited access to course material; lack of time for interactive knowledge consolidating activities during class, as the class time was spent by copying study material off the board; and, limited feedback on assessment tasks, as the only communication with students and the only opportunity to give feedback to the students was reduced to face-to-face interactions in class.

Frustrated by the limitations of the traditional ways of teaching, the instructor looked for alternatives. The instructor aimed to implement a new pedagogical approach ('before', 'during', and 'after' activities) that would facilitate three goals: (1, 'before') the preparation for the next class, and the revision of previous material at the beginning of each class; ( 2 , 'during') the incorporation of interactive learning activities during class; and (3, 'after'), better support, communication, assessment, and feedback on student assessment tasks. To achieve these goals, the instructor explored various available technologies and their potential to support the implementation of the 'before, during, after' framework; she concluded that the deployment of an educational web-based system could be a good solution, as illustrated in Table 2 . 
Table 2: Web-based applications; extending flexibility within pedagogical categories related to the main problems at DDA (adapted from Collis, \& Moonen, 2001, p. 21)

\begin{tabular}{|c|c|c|}
\hline Pedagogical Category & Web-based Applications & Relation to main problems \\
\hline Course organization & $\begin{array}{l}\text { a course calendar is available on } \\
\text { the web-based system site (before- } \\
\text { during-after activities) via which } \\
\text { relevant dates and times } \\
\text { - the updates are always available }\end{array}$ & $\begin{array}{l}\text { - it may help in solving } \\
\text { communication problems }\end{array}$ \\
\hline Lectures, contact sessions & $\begin{array}{l}\text { lecture notes and demonstration } \\
\text { materials are all available in the } \\
\text { course site (before-during-after ac- } \\
\text { tivities) } \\
\text { students do not have to be given } \\
\text { handouts and absent students do } \\
\text { not need to come to ask for hand- } \\
\text { outs later }\end{array}$ & $\begin{array}{l}\text { - enables efficient provi- } \\
\text { sion of content }\end{array}$ \\
\hline Self-study, assignments & $\begin{array}{l}\text { the instructor and students can add } \\
\text { additional study materials to the } \\
\text { course site without photocopying, } \\
\text { simply by uploading (before- } \\
\text { during-after activities) } \\
\text { the instructor can access the site } \\
\text { and check the assignments that } \\
\text { students have submitted look at } \\
\text { them directly from the site, give } \\
\text { feedback, and record marks (after } \\
\text { each activity) }\end{array}$ & $\begin{array}{l}\text { - enables efficient provi- } \\
\text { sion of content } \\
\text { - improves the quality of } \\
\text { feedback }\end{array}$ \\
\hline Major assignment & $\begin{array}{l}\text { detailed information about expec- } \\
\text { tations for the major assignment } \\
\text { can save many questions from stu- } \\
\text { dents (before-during-after activi- } \\
\text { ties) } \\
\text { the instructor can access the site } \\
\text { and check the assignments that } \\
\text { students have submitted look at } \\
\text { them directly from the site, give } \\
\text { feedback, and record marks (after } \\
\text { each activity) }\end{array}$ & $\begin{array}{l}\text { - improves provision and } \\
\text { quality of feedback }\end{array}$ \\
\hline Mentoring, communication & $\begin{array}{l}\text { 1. the instructor can contact students } \\
\text { whenever she wishes and answer } \\
\text { questions from the students at her } \\
\text { convenience } \\
\text { 2. the students can communicate with } \\
\text { each other or with her anywhere } \\
\text { and anytime (before-during-after } \\
\text { activities) }\end{array}$ & $\begin{array}{l}\text { 3. facilitates better commu- } \\
\text { nication (also outside } \\
\text { class) }\end{array}$ \\
\hline
\end{tabular}

The instructor decided to use the Blackboard Course Management System for the pilot implementation, as the system provided facilities for the management of course material, posting of an- 
nouncements, communication through discussion boards and emails, processing of assignments and quizzes, management of grades, and links to course website and other resources. The Blackboard Course Management System was chosen because of its popularity and convenience at that time. "It's easy to get started. The service is free, with an enhanced service available for a modest per course fee. Blackboard.com also features an extensive course catalog, from which learners can access a course their instructor has set up or search for distance learning courses" (Blackboard, 2004). Blackboard was selected also because it was the only system that offered a free trial version at the time. An introductory first-year course, 'Introduction to Computing', was selected for adaptation and delivery through Blackboard, as it was a mandatory course, the enrolled students were young (between 19 and 21 years of age) and, 90\% of the students already had good command of English and basic computer experience (MS Windows, MS Office) and were familiar with the internet.

The trial implementation involved several key parts of the course curriculum including topics on computer components, hardware and software, and computer service. The course was taught in English and Arabic. It was not possible to redesign the entire course as the free version of Blackboard was available only for 60 days. However, the implementation did address all three components of the 'before, during, and after' framework. For example, the 'before' component required students to carry out pre-class preparation such as identify from the Web examples that illustrated the study topics, annotate them, and submit them into the Blackboard environment for all participating students to use; this requirement aimed to encourage students to be proactive about their learning and generate discussion on study topics in class. In addition, the submitted materials from the previous class were to be used at the beginning of the subsequent class to facilitate the revision process. For the 'during' component, the instructor uploaded demonstration materials such as PowerPoint presentations, notes, and links into Blackboard on a weekly basis prior to the scheduled classes, and used these materials to deliver instruction during class; this online provision of lecture notes aimed to relieve the students from copying the notes during lectures. Lastly, the 'after' component involved uploading of follow-up activities that built upon and extended what happened during the face-to-face sessions; these activities aimed to give students the opportunity to complete assessment tasks online, individually or in groups, and receive timely and personalized feedback on their work. Chat rooms and e-mail were to be used in order to connect the students with each other and their instructor and, before starting the pilot course, the students were to participate in a week-long training course about using the Blackboard CourseManagement system.

The students' subsequent usage of the Blackboard solution concentrated in three areas: (1) access of course content; (2) completion of assessment tasks; and (3) communication with instructors and fellow students. All students regularly obtained course information from the Course Information Page (Figure 2) and referred to course content in the Lectures Pages (Figure 3). During the implementation trial, all students completed 3 assignments; they worked collaboratively online on the assignments, made online submissions, and received online feedback from their instructor. Students also regularly used communication tools such as email and chat room; while $90 \%$ of all students used email, $75 \%$ of them used it daily, and the remaining students used it 2 or 3 times a week. The chat tool was used by $67 \%$ of students; half of them used it 4 or 5 times per week, while the others used it weekly or less frequently. 


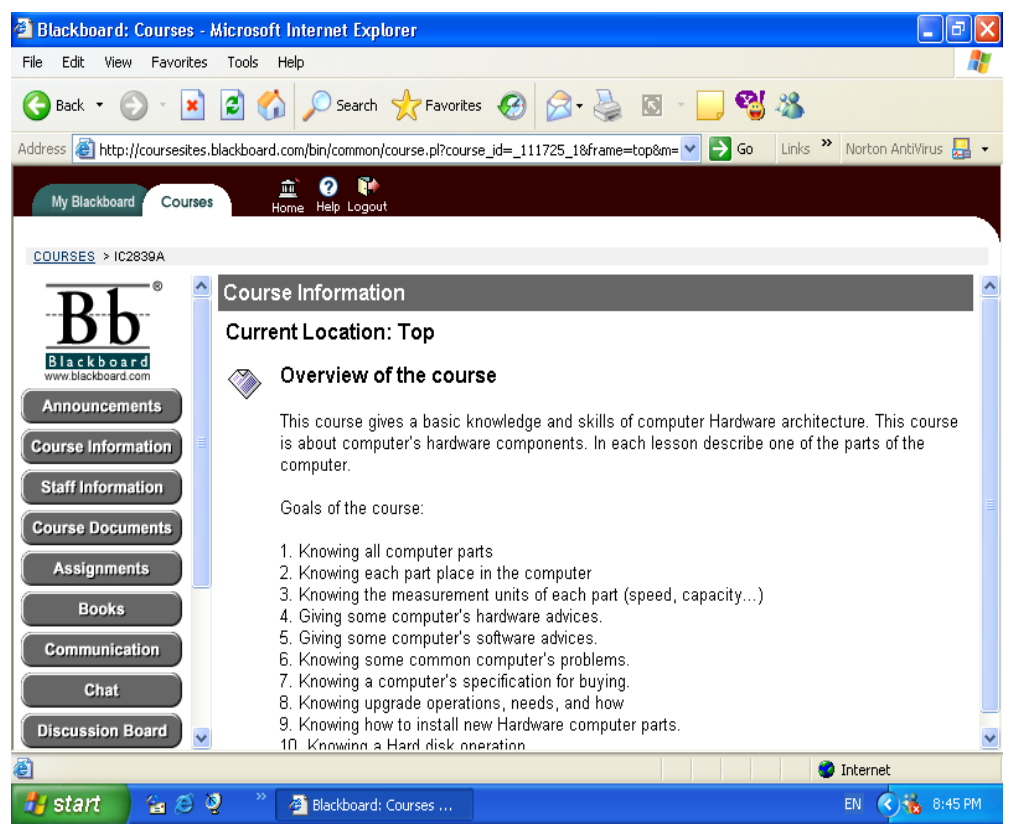

Figure 2: Course Information Page

The instructor's usage of the system focused on three different aspects: (1) posting the news and course information; (2) uploading online course content, assessment tasks, and feedback on student assessment tasks; and (3) communication with the students. The instructor regularly posted the news to students via the Announcement Page, and updated information about the course on the Course Information Page (Figure 2); there were 15 posts. During the implementation trial, the instructor spent almost 8 hours a day in front of a computer to observe the course's website; upload course lectures, and audio and video recordings of supplementary content material to the Lectures Pages (Figure 3); and, process assessment tasks, and students' feedback and grades on their assignments via the Assignments Page. The instructor also regularly replied to students' emails (at least 30 emails a day), and responded to student questions at any time, even during weekends; 1 or 2 hours a day were spent to contribute to the student chat group discussions (Rhema, 2005). 


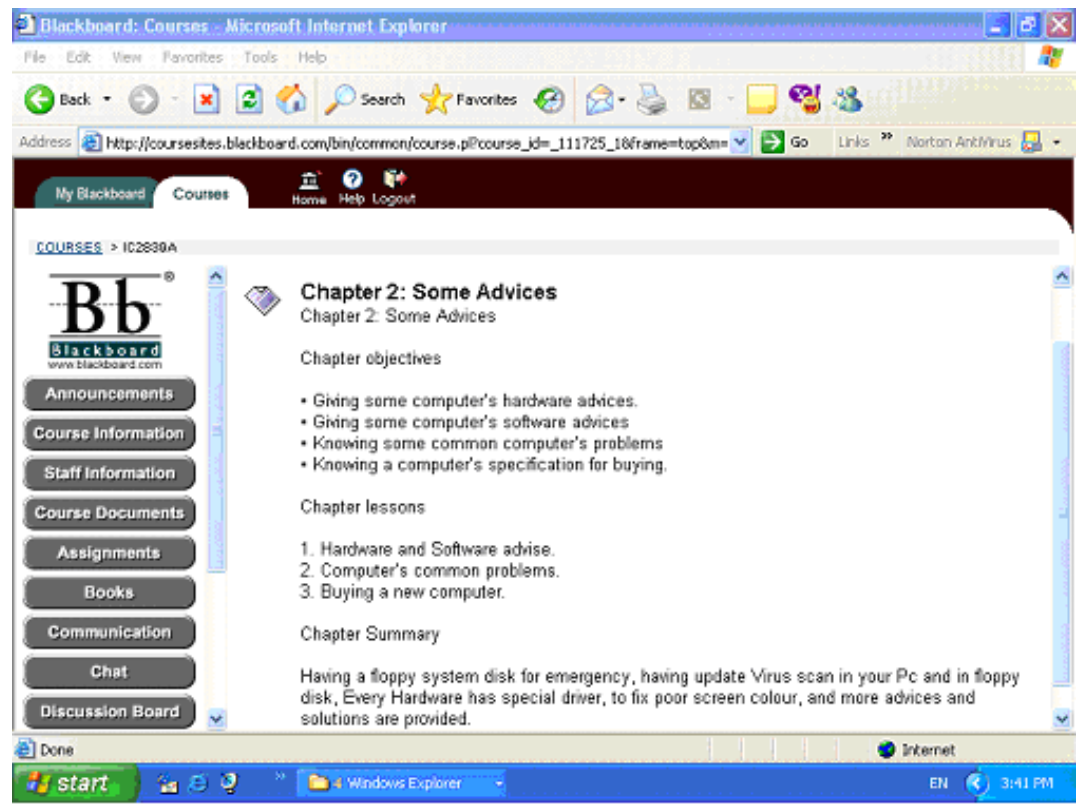

Figure 3: Lectures Page

\section{Stakeholders' Reflections on the E-Learning Trial}

An evaluation of the Blackboard-based initiative was conducted among students, instructors, and technical staff upon completion of the 60-day trial. A survey evaluation was conducted among the participating students and instructors (a different survey was administered to each group of respondents). The questions were designed to gather information about the effects (positive as well as negative) of using the Blackboard system on learning and teaching, and the extent to which it was useful in supporting the intended 'before, during, after' activities. In addition to the surveys, the evaluation involved phone interviews with technical staff, the course instructor and another instructor assisting in the redesigning of the course and uploading it online.

\section{Student Reflections}

Students appreciated the Blackboard-assisted offering of the course and reported its positive impact on their communication with instructors and fellow students, group work, submission of assignments, feedback on assessment tasks, quality of their learning experience, and their attitudes towards web-assisted learning. Inadequate technical support was identified by the students as only negative aspect of the project.

Students regarded the resulting improvements in communication as important, appreciating the opportunity to keep in contact with instructors and with each other via the Web at all times without needing to wait to see each other in face-to-face sessions. Some students also reported an increase of online communication in their private lives:

"The most common improvement was communication, which without would render the learning and teaching processes insignificant."

"It provides communication facilities so we can easily interact and ask questions of our instructor and other students at anytime and anywhere."

"We started to use the email system supported by the web-based system as fun for our personnel use as well." 
Positive impact on group work and assessment was noted, particularly the introduction of formative assessment enabled by the Blackboard system and, associated with it, improved quality of feedback provided to students:

"The ideas of using an individual assignment and group assignment for the assessment become applicable; we can share our experiences while we are in different places, and no time or place has to be scheduled for this."

"Because the instructor started to use assessment for the assignments, and quizzes supported by the web-based system, and then she gives us feedback, our performance in the course has progressed."

"By using web-based system our instructor started giving the individual and group assignments instead of just relies on two exams per semester for the assessment."

Efficient provision of course content was welcome by students, especially the availability of lecture materials online, which relieved them from copying the material off the board during lectures:

"We do not have to write down all the text that has been written by the instructor on the board."

"We can check class notes if sick and reference for assignment."

"It's there whenever we need it. We can take our time reading through it."

"It makes the demonstration materials available via the course site so we can catch the information at any time."

Students valued the new way of learning and teaching afforded by the Blackboard experience; they particularly appreciated the shift away from a teacher-centred approach and towards a student-centred one:

"It encourages us to develop new learning schemes, ideas and knowledge."

"With this approach we got nice experience and we felt the information remained more than the traditional teaching."

"We are more motivated than with just teacher-centred teaching, which is really excellent."

"Our instructor provided opportunities for us to search for the ways of learning, make choices about our own learning methods, and self-evaluate learning progress."

In addition to reporting positive impact on their learning, students expressed excitement and interest in using a web-based system for learning:

"It looked difficult to use in the beginning but after that it was easy and enjoyable."

"We wish to discover all the features of Blackboard and use it for all the subjects."

"We really liked this approach and we hope it can be implemented largely to improve the system and we hope to see soon the web-based system implemented in all the higher education institutions in the State of Libya."

Inadequate technical support was the only negative aspect reported by the students. They complained about limited expertise as well as availability of the technical staff:

"Each time we need help we have gone to the help desk, but no one is there". 


\section{Instructor Reflections}

Instructors valued the Blackboard-assisted delivery of the course and reported its positive impact on their communication with students, provision of feedback on assessment tasks, quality of their teaching experience, and their attitudes towards web-assisted teaching. However, the instructors were concerned about the increase in their work load, and the inadequate provision of technical support.

Instructors regarded the resulting improvements in communication as important, appreciating the opportunity to keep in contact with their students via the Web at all times without needing to wait to see each other in face-to-face sessions. Some instructors also reported the use of online communication was more convenient:

"It provides required communication facilities; I can easily interact with my students (the groups of students and individuals) at any time."

"The conversations and interactions between instructors and students have become easier."

Instructors welcomed the opportunity to introduce formative assessment into the course; they particularly valued the benefits of individual and group assignments enabled by the Blackboard system and, associated with them, improved opportunity to provide quality feedback to students:

"By using web-based system I have started giving the individual and group assignments to my students instead of just rely on two exams per semester for the assessment, which have positive impact on students' learning."

"It helps me to give better feedback to my students (the groups of students and individuals)."

"It enables the instructors to send quick feedback to their students immediately without needing to wait to see each other in face to face sessions."

Efficient provision of course content was valued by instructors, especially the opportunity to provide the lecture materials online, which relieved them from writing the lecture material on the board during class and freed up class time:

"The instructors do not have to write the content of the course on the board or to provide the content to their students when they are absent."

"I believe that this learning environment is one that presents materials to students in timely manner and in a way that best suits their learning style."

"It allows materials to be delivered in a time and place that suits the students using them; this environment can act as a repository of course information and a gateway to wider information for learners at anytime and anywhere."

Instructors appreciated the new way of teaching and learning afforded by the Blackboard experience; they particularly welcomed the shift away from a traditional teacher centred teaching method to a more integrated approach, and the great impact on student learning outcomes:

"It helps students to be prepared to take the responsibility for their own learning. I am going to be more of a problem solver, someone there in case I am needed, and my students are more self-directed learners."

"Instructors become facilitators of the learning process directing students to appropriate resources, tasks and learning outcomes." 
"It enables students to learn collaboratively from one another. For many students, this is a significant shift, and one for which they need to be adequately prepared.

The students respond to this approach, they are more motivated and made remarkable progress than with just face-to-face teaching, which is a great impact."

In addition to reporting positive impact on their way of teaching, instructors expressed enjoyment and interest in using a web-based system for teaching:

"The use of web-based system motivates my interest in teaching. It is more interesting and more flexible when compared to the traditional method. It provides me and my students with different tools and media. It's exactly what I and other instructors need."

"Web-based system added a lively and renewed atmosphere in the classroom "now". As I have been teaching this course for several years, sessions started to be more routine from day to day and my role was just to check the title of the session to start explaining the information I had already "before"."

"Such project should be used and implemented in the general public universities in Libya, to enable students improve their learning achievement. "

However, the instructors noted the increased workload associated with delivering the course through Blackboard and expressed concern about the extra time and effort required:

"I spent more than 8 hours per day in front of the computer to observe the course's website, also to see the new information offered from both instructor and fellow students and submit comments, to check my email, and reply to my students at any time even during weekends."

"The instructor's work load will increase because of the changes in their roles, instructor will spend much more time in front of the computer to upload or modify courses' contents, reply to students' e-mails, answer questions, and contribute to the students chatting group discussions. As the instructor monitors more groups, he/she needs to spend more time and effort."

Inadequate technical support was another negative aspect reported by the instructors. They saw the limited expertise, as well as availability, of the technical staff as great challenges for implementing the web-based system:

"I lacked confidence that technical support would be available and able to solve the technical problem when I needed it. This is considered as a great barrier when using web-based system."

\section{Reflections of Technical Staff}

The interview with the technical staff member revealed that he noted the benefits of Blackboard as a tool for interaction between instructors and students:

"By using web-based system, students can learn and interact with their instructor and with each other any time, any place and at their own pace. It improves the way of teaching, learner's activities and collaborative learning."

He was pleased to be involved in the first ever implementation of a web-based system in the Department, and considered his expertise as adequate. However, he noted that the implementation could benefit from better student and instructor training and technical support from the system vendor; he looked forward to future implementations in other courses: 
"I appreciate the work as a first start of introducing a web-based system in Data Analysis Department program, and I wish to see it uses to deliver all subjects."

"I provide one-to-one support if the instructor and/or students have any access and/or any technical problems."

"I think that it is important that people doing e-learning are trained in how to develop good e-learning courses and to use it effectively before being let loose. If not the result is something that does not help students, and harms the instructors and the institution."

"Some technical staff from a software company need to stay some time at the department to make sure everything is effectively running."

The technician regarded the infrastructure in the Department as sufficient to run a web-based system; however, he thought that an update of the existing workstations and the local network could improve its performance:

"The number of PCs computer has to be increased, as well as the existing PCs, workstations and local network services have to be updated."

\section{Discussion and Conclusion}

The reflections of students, instructors, and technical staff on the pilot e-learning initiative in the Department of Data Analysis at the Aljabal Algharbi University in Libya indicate a positive attitude towards e-learning/web-based system among all concerned. This positive outlook of the participating students and staff, and the associated success of the e-learning pilot, was an outcome foreshadowed by the preceding SWOT analysis. According to the analysis, the introduction of web-based instruction (e-learning) was likely to be successful, considering the Department's strengths: wide use of computers for teaching and learning; well-equipped computer laboratories; and, good computing skills among instructors and students.

The reflections of the participating students and instructors on the e-learning pilot revealed that the initiative has achieved its objectives with respect to supporting the 'before, during, after' framework; indeed, all three components of the framework appeared to be equally well supported. Students and instructors were in agreement that the efficient online provision of course content particularly satisfied the requirements of the 'before' and 'during' components; it enabled revisions of course material prior to classes, and freed class time by removing the need to copy material off the board during classes. The 'during' component was also supported by the introduction of interactive learning activities during classes enabled by the freed up class time. Both students and instructors embraced the new way of teaching and learning (a more student-centred approach) and stressed its positive impact on student learning outcomes comparing to the results of the same students in the same course when only face-to-face sessions were used during the beginning of the semester (before the trial). The participants commented also on the improvements brought on by the e-learning initiative with respect to communication, group-work, assessment, and feedback, that is the 'after' component of the pedagogical framework.

Inadequate technical support was reported as a relatively minor concern by both students and instructors; they complained about limited expertise as well as availability of the technical staff. However, the technical staff suggested that the issue could be overcome by the provision of better induction training to students and staff, and better ongoing technical support from the system vendor. In addition, the instructors expressed concern about the increase in their work load associated with delivering the course online. However, they felt that the problem could be alleviated by a gradual introduction of the various features of the e-learning system. 
Despite the reported success of the pilot e-learning initiative in the DDA, there have been no significant changes towards the implementation of e-learning in this Department since the pilot implementation. The situation appears to be similar in other higher education institutions in Libya and e-learning still remains an unexplored entity in many developing nations. Many conceptual boundaries such as technological, pedagogical, social and economic have yet to be fully understood and explored (Duan et al., 2010; Rossiter \& Crock, 2006). Further research is needed to explore and determine the characteristics, enablers, and challenges of educational settings as related to ICT and e-learning in higher education in Libya; one such research study, conducted by one of the authors of this paper, is currently underway. The study investigates the experiences with, and perceptions of ICT, among students and educators in selected higher education programs in Libya to determine their preparedness to adopt ICT and e-learning in teaching and learning. It is hoped that the findings of the research study will serve as source of information for academics, administrators, and decision-makers involved in planning, design and implementation of e-learning in Libya.

\section{References}

Andersson, A., \& Grönlund, A. (2009). A conceptual framework for e-learning in developing countries: A critical review of research challenges, The Electronic Journal on Information Systems in Developing Countries, 38(2), 1-16.

Artemi, M., \& Kuma, A. (2009). A SWOT Analysis of e-learning model for the Libyan educational institutions. Proceedings of the 3rd National Conference of Basic Science 25-27/4/2009 Aljabal Algharbi University Gharian - Libya, 6-11.

Blackboard Course Management System. (2005). Transforming the Internet into a powerful environment for the education experience. Retrieved November 10, 2004 from http://www.blackboard.com

Boulton, H. (2008). Managing e-learning: What are the real implications for schools? Electronic Journal eLearning, 6(1), 11-18.

Chan, S. P., \& Welebir, B. (2003). Strategies for e-education. Industrial and Commercial Training, 35(5), 196-202.

Collis, B. A., \& Moonen, J. (2001). Flexible learning in a digital world: Experiences and expectations. London: Kogan Page.

Dhanarajan, G. (2001). Distance education: Promise, performance and potential. The Journal of Open and Distance Learning, 16(1), 61-68.

Duan, Y., He, Q., Feng, W., Li, D., \& Fu, Z. (2010). A study on e-learning take-up intention from an innovation adoption perspective: A case in China. Computers and Education, 55(1), 237-246.

Eastmond, D. (2000). Realizing the promise of distance education in low technology countries. Educational Technology Research and Development, 48(2), 100-111.

Evans, R. (2005). Explaining low learner participation during interactive television instruction in a developing country context. PhD Dissertation, University of Pretoria, Pretoria. Retrieved September 17, 2010 from http://upetd.up.ac.za/thesis/submitted/etd-02282005-081708/unrestricted/00front.pdf

The General People's Committee of Education. (2008). The development of education. National report of Libya, Geneva 25- 28 November 2008. Retrieved September 17, 2010 from http://www.ibe.unesco.org/National Reports/ICE 2008/libya NR08.pdf

Ghazinoory,S., Zadeh, A., \& Memariani, A. (2007). Fuzzy SWOT analysis. Journal of Intelligent \& Fuzzy System, 18(1), 99-108. Retrieved September 17, 2010 from http://iospress.metapress.com/content/3pxfql7kh2udep7j/fulltext.pdf

Gulati, S. (2008) Technology-enhanced learning in developing nations: A review. International Review of Research in Open and Distance Learning, 9(1), 1-16. 
Hamady, A. (2007). ICT in Education in Libya. Libya Country Report. Retrieved September 17, 2010 from http://www.infodev.org/en/Document.412.pdf

Heeks, R. (2002). Information systems and developing countries: Failure, success and local improvisations. The Information Society, 18(2), 101-112.

Hodgkinson-Williams, C., Siebörger, I., \& Terzoli, A. (2007). Enabling and constraining ICT practice in secondary schools: Case studies in South Africa. International Journal of Knowledge and Learning, $3(2 / 3), 171-190$.

Khan, B. (2005). Managing e-learning: Design, delivery, implementation, and evaluation. Information Science Publishing.

Leigh, D. (2010) SWOT analysis. In R. Watkins \& D. Leigh (Eds.), Handbook of improving performance in the workplace, Volume two: Selecting and implementing performance interventions (pp. 115-140). Hoboken, NJ, USA: John Wiley \& Sons, Inc. doi: 10.1002/9780470587102.ch5

Lin, Q. (2008). Student satisfactions in four mixed courses in elementary teacher education program. Internet and Higher Education, 11(1), 53-59. Retrieved October 17, 2010 from http://113.212.161.150/elibrary/Library/Higher_Education/Lin_Student.pdf

Mohammad, E. (2008). Framework for e-learning strategy in the Egyptian universities. Proceedings of the IADIS International Conference e-Learning, 58(4), 21-26.

Rajesh, M. (2003). A study of the problems associated with ICT adaptability in developing countries in the context of distance education. The Turkish Online Journal of Distance Education, 4(2). Retrieved September 17, 2010 from http://tojde.anadolu.edu.tr/tojde10/articles/Rajesh.htm

Rhema, A. (2005). Towards flexible learning: Implementing web-based learning in the Data Analysis Department of the Faculty of Economics and Accounting of the "Aljabal algharbi University" in Gharian in Libya. Unpublished Master thesis, Faculty of Behavioural Science, University of Twente, Enschede, The Netherlands.

Rhema, A., \& Miliszewska, I. (2010). Towards e-learning in higher education in Libya. Issues in Informing Science and Information Technology, 7, 423-437. Retrieved from http://iisit.org/Vol7/IISITv7p423437Rhema735.pdf

Richter, T., \& Pawlowski, J. (2007). Context and culture metadata - A tool for the internationalization of elearning. In C. Montgomerie \& J. Seale (Eds.), Proceedings of World Conference on Educational Multimedia, Hypermedia and Telecommunications (pp. 4528-4537). Chesapeake, VA: AACE.

Rossiter, D. E., \& Crock, M. (2006). Embedding e-learning: A new perspective on change and innovation. International Journal of Learning Technology, 2(4), 279-293.

Sehrt, M. (2003). E-learning in the developing countries - Digital divide into digital opportunities. UN Chronicle Online, 4(3), 45-xx.

UNESCO. (2002). Information and communication technologies in teacher education - A planning guide. [Report.] Retrieved September 17, 2010 from http://unesdoc.unesco.org/images/0012/001295/129533e.pdf

Vrana, V., Fragidis, G., Zafiropoulos, C., \& Paschaloudis, D. (n.d.). Analysing academic staff and students' attitudes towards the adoption of e-learning. Retrieved September 17, 2010 from http://asiapacificodl.oum.edu.my/C70/F275.pdf

Yuksel, I., \& Dag deviren, M. (2007). Using the analytic network process (ANP) in a SWOT analysis - A case study for a textile firm. Information Sciences, 177(16), 3364-3382. 


\section{Biographies}

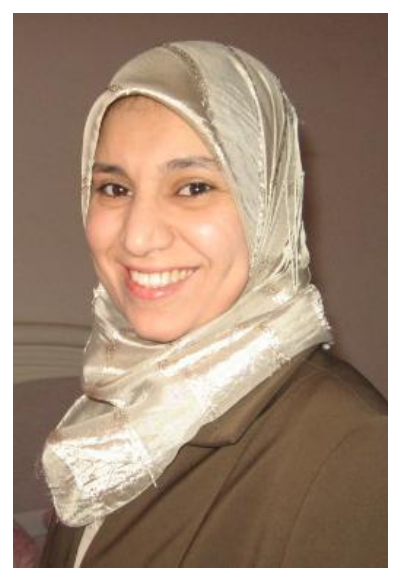

Mrs Amal Rhema is a PhD candidate in the School of Engineering and Science at Victoria University in Melbourne, Australia where she is currently undertaking a research project entitled "An analysis of experiences and perceptions of technology-based learning in higher education institutions in Libya: informing the advancement of e-learning through case studies".

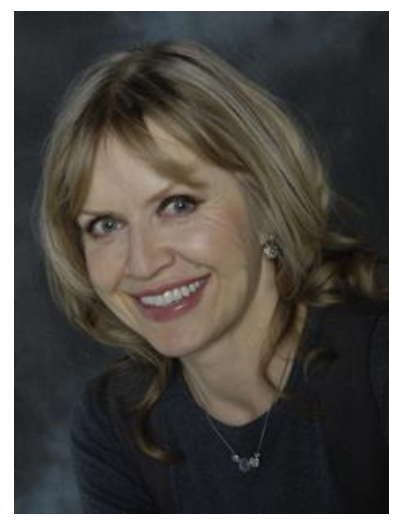

Dr Iwona Miliszewska is Associate Professor in computer science at Victoria University in Melbourne, Australia. She has led and participated in research projects involving transnational education, effective teaching methods, females in ICT, and technology supported learning and has published in these areas. 